\title{
超音波によるフィルム基板液晶セル内の 微小気泡の検出に関する研究
}

堀 三 計*1 $\cdot$ 江 口 元 $^{* 2}$

\section{The Detection of Micro Bubbles in a Film Substrate Liquid Crystal Cell Using Ultrasonic Technique}

\author{
Hori, Sankei*1/Eguchi, Hajime*2
}

A film substrate liquid crystal cell was researched and developed as an advanced display. The display has a lot of advantages, such as light, thin, and not easy to crack. It is manufactured by Roll-to-Roll process. In this manufacturing process, the automatic detecting method of the bubble in the liquid crystal layer is required. When the bubbles are in the liquid crystal layer, the part where the bubble exists cannot be displayed. It is called "missing dots". Therefore, it is very important to detect the bubble in the liquid crystal layer. But, the bubble under the black matrix cannot be detected by an optical method. Its diameter is $10 \mu \mathrm{m}$ or less.

In this study, a method to detect the bubble of $10 \mu \mathrm{m}$ or less in diameter using an ultrasonic technique was studied. Owing to the instability of the bubble in the crystal layer, drilled holes and silica balls were used as detection objects instead of bubbles.

As a result, it was indicated that the drilled hole of the size of about $30 \%$ of the focus diameter of the ultrasonic probe can be detected. The attenuation coefficient in the film of the ultrasonic wave of frequency $250 \mathrm{MHz}$ was about 4. 3. The silica balls of $5.5 \mu \mathrm{m}$ or $5 \mu \mathrm{m}$ in diameter was detected using the ultrasonic probe of frequency $250 \mathrm{MHz}$ and of $6 \mu \mathrm{m}$ in focal diameter. Moreover, the bubble of $10 \mu \mathrm{m}$ or less in diameter was clearly observed.

Key words : Film based display/Bubble/Liquid crystal/Ultrasonic technology

\section{1. 緒言}

次世代モバイルディスプレイとして薄型, 軽量で割れに くい樹脂フィルムを基板としたディスプレイが研究・開発 されている.このディスプレイは, Roll-to-Roll プロセス で製造することを目的としており，生産性が高く，実用化 が望まれている，他方, 液晶内に気泡が混入すると, 画素 欠陥（いわゆるドット抜け）が生じて画像を表示できなく なる。

このため, 液晶内に混入した気泡をインプロセスで検出 する方法が求められている. 現在, ガラス基板液晶ディス プレイの画素欠陥検査には, 肉眼による方法, CCD カメ

${ }^{* 1}$ 筑波大学

つくば市天王台 1-1-1（３05-8577）

University of Tsukuba

1-1-1, Tennodai, Tsukuba, 305-8577, Ibaraki

hori.sankei.fn@u.tsukuba.ac.jp

*2 東京農工大学 产官学連携・知的財產センター

小金井市中町 2-24-16（宁184-8588）

Tokyo Univ. of Agriculture and Technology, Center for Innovation and Intellectual Property

2-24-16, Nakacho, Koganei-shi, 184-8588, Tokyo 2011.7.22 受理
ラを利用した画像処理システムによる方法などの光学的方 法 ${ }^{1), 2}$ が主に使われている. しかし，ブラックマトリック スの下に隠れた小さな気泡は光学的方法で検出することは できない，また，気泡は液晶内を移動する可能性があり， ブラックマトリックスの下に隠れていた気泡が，RGB カ ラーフィルター部分へ移動すると画素欠陥の原因となる. このため, ブラックマトリックスの下に隠れている気泡を 検出する必要がある.

光学的方法以外の非破壊検査方法としては, X 線 ${ }^{3)}$ や超 音波を利用した方法 ${ }^{4), 5)}$ が挙げられる。しかし，X線は人 体に有害である. また, 超音波を利用した方法では検出可 能な気泡や異物の大きさについて系統的に調べられた例は ない.

そこで, 本研究では超音波で検出可能な気泡の大きさを 系統的に調べ，ブラックマトリックス下にある直径 $10 \mu \mathrm{m}$ 以下の微小気泡を超音波で検出する方法について検討する ことを目的とした.

なお，微小気泡は消滅したり移動したりして安定しない ため, 微小気泡の代わりに樹脂フィルム表面にマイクロド リルであけた微小な穴を種々の焦点径や周波数の超音波プ ローブを使って観察した。

また, 気泡の代わりにフィルム基板液晶セルの液晶に混 
入した微小なシリカ球や，フィルムで挟んだ水の層に混入 した気泡の観察も行った.

\section{2. 実験装 置}

本研究では, 株式会社日立エンジニアリング・アンド・ サービスの超音波映像装置（型式：FS 300）を使用して観 察を行った. 取り付け可能な超音波プローブの周波数は 1 〜 300 MHz, プローブの最大走查速度は $1 \mathrm{~m} / \mathrm{s}$ である.

実験に使用したフィルム基板液晶セルの概略を図 1 に示 す.フィルム基板液晶セルは, 厚さ $5 \mu \mathrm{m}$ の液晶を厚さ $100 \mu \mathrm{m}$ のポリプロピレン製フィルム基板で挟んだ構造と なっている.また，液晶とフィルム基板の間には，厚さ $0.15 \mu \mathrm{m}$ の透明電極と厚さ $0.05 \mu \mathrm{m}$ の配向膜がある. な お, 液晶には, 直径 $5 \mu \mathrm{m}$ のシリカ球がスペーサとして入
れてある。

このフィルム基板液晶セルの液晶内に微小な気泡を混入 すると，移動したり消滅したりするため，種々の大きさの 気泡を安定して混入することは難しい. そこで, 種々の大 きさの気泡の代わりに，図 $2(\mathrm{a})$ に示すように，フィルム 基板と同材質の厚さ $210 \mu \mathrm{m}$ のフィルムにマイクロドリル で穴をあけた試料 A の観察を行った。穴あけに使用した マイクロドリルの直径は, $40 \mu \mathrm{m}, 70 \mu \mathrm{m}, 100 \mu \mathrm{m}$ であ る。なお，本研究では穴をあけていないフィルムを試料 $\mathrm{B}$ として使用した。 また，図 $2(\mathrm{c})$ に示すように気泡の代わ りに直径 $5.5 \mu \mathrm{m}$ のシリカ球をフィルム基板液晶セルの液 晶に混入した試料 C を使って液晶内のシリカ球の観察を 行った.さらに, $210 \mu \mathrm{m}$ のフィルムをガラス板に両面テー プで貼り付けてその間に液晶の代わりに水を封入し，故意

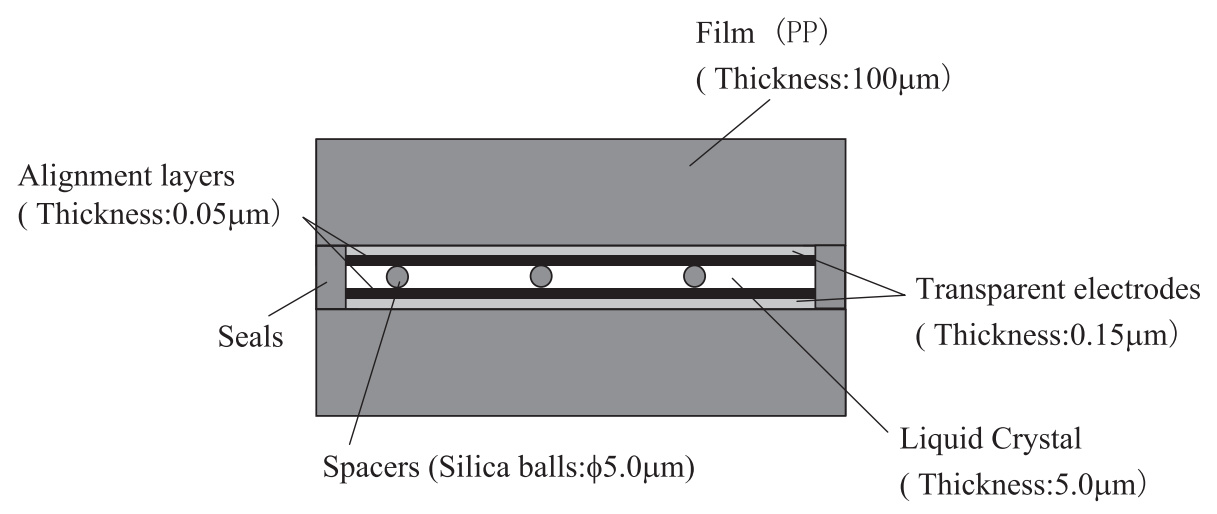

Fig. 1 Schematic view of a film substrate liquid crystal cell

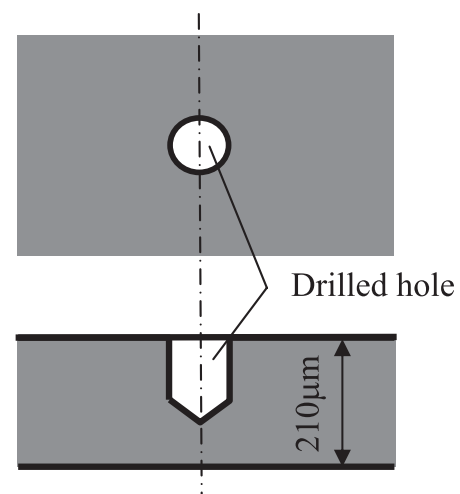

(a) Test piece $\mathrm{A}$ (Film with drilled hole)

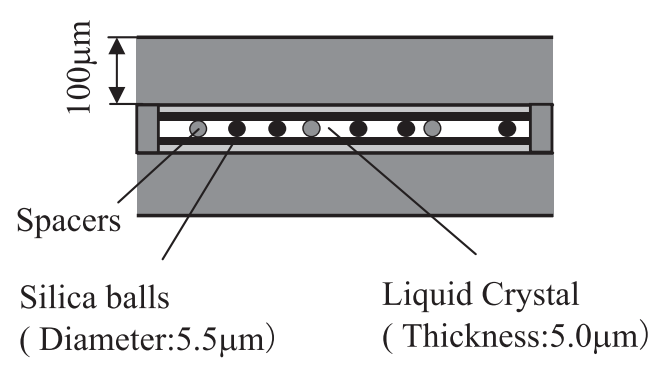

(c) Test piece C

(Film substrate liquid crystal cell with silica balls)

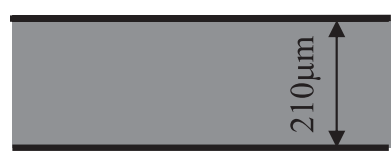

(b) Test piece B

(Film without drilled hole)

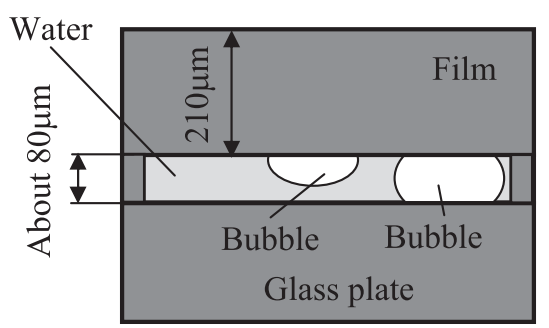

(d) Test piece $\mathrm{D}$ (With bubbles)

Fig. 2 Test pieces 
に気泡を入れた試料 D について気泡の観察を行った。

本研究で使用した超音波プローブの一覧を表 1 に示す. 本研究で使用したプローブは焦点型で，その周波数は 10 $\mathrm{MHz} \sim 250 \mathrm{MHz}$ ，焦点径（直径）は水中で $6 \mu \mathrm{m} \sim 410 \mu \mathrm{m}$, 焦点距離は水中で $1.2 \mathrm{~mm} \sim 25.4 \mathrm{~mm}$ である. 本研究では, 試料を水中に入れて測定する水浸法で測定した.

\section{3 . 測定原理と検討事項}

フィルム基板液晶セルにはフィルム基板と液晶との間に 配向膜（厚さ $0.05 \mu \mathrm{m}$ ） と電極（厚さ $0.15 \mu \mathrm{m}$ ）がある. しかし, 厚さが極めて薄く均一に付着しているため, 本測 定方法にはほぼ影響がないと考えられる。そこで，フィル ム基板液晶セルをフィルム基板 - 液晶 -フィルム基板の 3 層で構成された物体と考える。 この物体に超音波映像装置 に取り付けられた超音波プローブから超音波が投射される と図 3 に示すような反射波が得られる。

具体的には，超音波プローブから投射された超音波は， 水中を伝播して水とフィルム基板との境界面（境界面 $\mathrm{I}_{1}$ ) で一部が反射して反射波 S として観察される。境界面 $\mathrm{I}_{1}$ を透過した超音波はフィルム基板と液晶の境界面（境界面 $I_{2}$ ) で一部が反射し, 反射波 $F$ が観察される.ささらに, 液 晶に透過した超音波の一部は液晶とフィルム基板の境界面 (境界面 $\mathrm{I}_{3}$ ) で反射して反射波 B が観察される.

このとき，境界面 $\mathrm{I}_{1}, \mathrm{I}_{2}, \mathrm{I}_{3}$ における超音波の音圧反射 率 $r_{1}, r_{2}, r_{3}$ の值は, 次式で表される.

$$
\begin{gathered}
r_{1}=\left|\left(Z_{F}-Z_{W}\right) /\left(Z_{F}+Z_{W}\right)\right| \\
r_{2}=r_{3}=\left|\left(Z_{C}-Z_{F}\right) /\left(Z_{C}+Z_{F}\right)\right|
\end{gathered}
$$

ここで, $Z$ は各媒質の音響インピーダンスで, 音速と密度 の積である．添え字 $\mathrm{W}, \mathrm{F}, \mathrm{C}$ はそれぞれ水，フィルム基

Table 1 Frequency, focal diameter, and focal length of ultrasonic probes used in this study

\begin{tabular}{l|c|c|c|c|c|c|c|c}
\hline \hline Frequency $(\mathrm{MHz})$ & 5 & 10 & 25 & 50 & 85 & 140 & 200 & 250 \\
\hline Focal diameter $(\mu \mathrm{m})$ & 410 & 275 & 130 & 80 & 32 & 6 & 6 & 6 \\
\hline Focal length $(\mathrm{mm})$ & 25.4 & 25.4 & 12 & 12 & 8.1 & 1.7 & 1.2 & 1.2 \\
\hline
\end{tabular}

板, 液晶を示す.

水平に置かれたフィルム基板液晶セルの液晶に微小な気 泡が混入した場合，気泡は浮力によってフィルム基板と液 晶の境界面（境界面 $\mathrm{I}_{2}$ ）に付着すると考えられる. 空気の 音響インピーダンスはほぼ $0 \mathrm{~N} \cdot \mathrm{s} / \mathrm{m}^{3}$ であるため, フィル 么基板と気泡の境界面の音圧反射率はほぼ 1 となる。この ため, 投射された超音波はフィルム基板と空気の境界面で ほぼ全反射し, 液晶へは伝播しない。しかし, 液晶の音響 インピーダンスは $0 \mathrm{~N} \cdot \mathrm{s} / \mathrm{m}^{3}$ ではないため, 液晶と接して いる部分では一部の超音波が液晶層へ透過し,全反射しない.

このため，フィルム基板と液晶との境界面 $\mathrm{I}_{2}$ における 反射波 $\mathrm{F} の$ 振幅変化を測定すれば液晶内の気泡を検出で きると考えられる。

本研究では，フィルム基板液晶セル内の微小気泡を超音 波で検出するために，以下の 3 つの点について検討した.

(1)超音波の焦点径と検出可能な気泡の大きさ：微小気泡を 検出する場合には，超音波プローブの焦点径と検出可能な 気泡の大きさの関係を明らかにする必要がある。一般的に は，焦点径が小さければ小さな物体の検出が可能である. また，焦点径が大きくなると小さな物体は焦点径内に占め る面積が小さくなるために, 反射波振幅の変化が小さくな り, その検出が難しくなる. しかし, 検出対象の大きさと

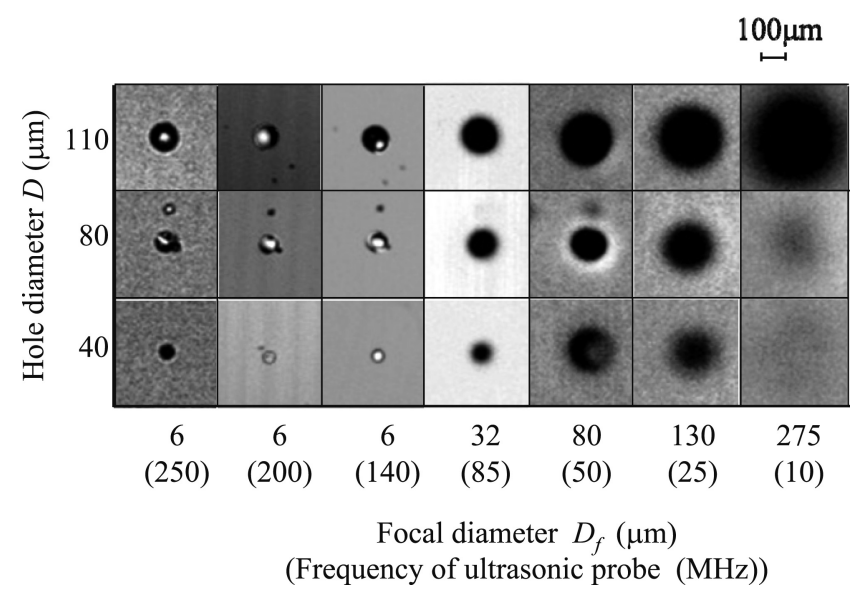

Fig. 4 Observed results of drilled holes using scanning acoustic tomograph

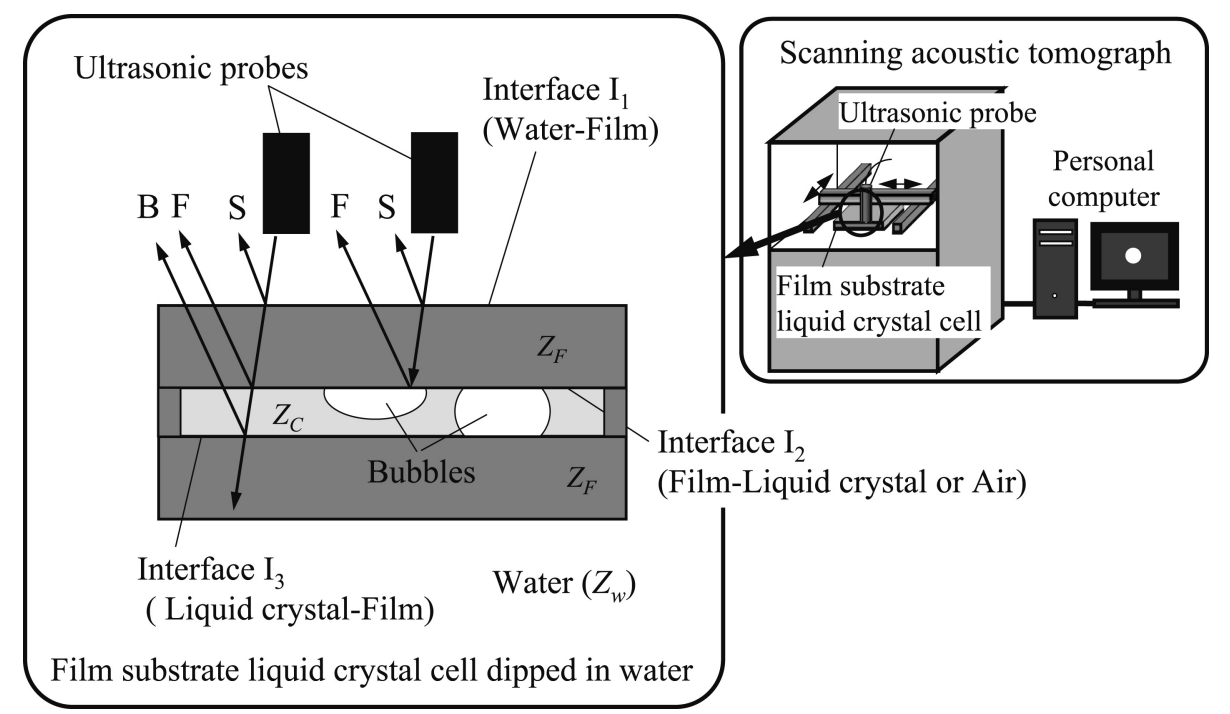

Fig. 3 Reflected echoes in a film substrate liquid crystal cell 
焦点径の関係は系統的に調べられていない.

(2)超音波の減衰：超音波が物体内を伝播すると減衰する.

一般に, 超音波の焦点径が小さくなると周波数が高くなる また，周波数が高くなると減衰は大きくなる．このため,

フィルム基板液晶セル中の気泡を検出するためには，その 減衰の大きさを明らかにする必要がある.

(3)微小なシリカ球や気泡の観察：液晶や水中に混入したシ リカ球や気泡がどのように観察されるかを明らかにし, シ

リカ球のような異物と気泡の観察上の違いについて明らか にする。

本研究では, 上記(1), (2), (3)について超音波映像装置を 利用して検討した.

\section{4. 実験結果及び考察}

\section{1 超音波の焦点径と検出可能な大きさ}

今回使用した超音波プローブの中で最も周波数が高くて 焦点径が小さい, 周波数 $250 \mathrm{MHz}$, 焦点径約 $6 \mu \mathrm{m}$ の超音 波プローブを使って, 試料 Aのドリル穴を観察し, 穴直 径を測定した。その結果，穴あけに使用したドリル直径が $40 \mu \mathrm{m}, 70 \mu \mathrm{m}, 100 \mu \mathrm{m}$ に対して，測定された穴直径は それぞれ約 $40 \mu \mathrm{m}$, 約 $80 \mu \mathrm{m}$, 約 $110 \mu \mathrm{m}$ となり, ドリル 直径とほぼ同じ直径となった。

これらの穴を種々の周波数と焦点径の超音波プローブで 観察した結果を図 4 に示す。なお，本研究で使用した超音 波映像装置では，超音波反射波振幅が小さいと黒く，大き

Table 2 Ratio of hole area $\left(S_{1}\right)$ and focal area $\left(S_{2}\right)$, $\mathrm{S}_{1} / \mathrm{S}_{2}$, and ratio of hole diameter $\left(\mathrm{D}_{1}\right)$ and focal diameter $\left(D_{2}\right), D_{1} / D_{2}$

\begin{tabular}{|c|c|c|c|c|c|c|c|}
\hline & & \multicolumn{5}{|c|}{ Focal diameter $D_{2}(\mu \mathrm{m})$} \\
\hline & & & 6 & 32 & 80 & 130 & 275 \\
\hline \multirow{3}{*}{ 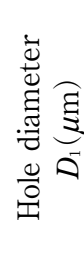 } & 110 & $\begin{array}{c}S_{1} / S_{2} \\
\left(D_{1} / D_{2}\right)\end{array}$ & $\begin{array}{c}336 \\
(18.3)\end{array}$ & $\begin{array}{c}11.8 \\
(3.43)\end{array}$ & $\begin{array}{c}1.90 \\
(1.38)\end{array}$ & $\begin{array}{c}0.72 \\
(0.85)\end{array}$ & $\begin{array}{c}0.16 \\
(0.40)\end{array}$ \\
\hline & 80 & $\begin{array}{c}S_{1} / S_{2} \\
\left(D_{1} / D_{2}\right)\end{array}$ & $\begin{array}{c}177 \\
(13.3)\end{array}$ & $\begin{array}{c}6.25 \\
(2.50)\end{array}$ & $\begin{array}{c}1.00 \\
(1.00)\end{array}$ & $\begin{array}{c}0.38 \\
(0.62)\end{array}$ & $\begin{array}{c}0.08 \\
(0.29)\end{array}$ \\
\hline & 40 & $\begin{array}{c}S_{1} / S_{2} \\
\left(D_{1} / D_{2}\right)\end{array}$ & $\begin{array}{c}44.5 \\
(6.67)\end{array}$ & $\begin{array}{c}1.56 \\
(1.25)\end{array}$ & $\begin{array}{c}0.25 \\
(0.50)\end{array}$ & $\begin{array}{c}0.10 \\
(0.31)\end{array}$ & $\begin{array}{c}0.02 \\
(0.15)\end{array}$ \\
\hline
\end{tabular}

いと白く観察される．本研究では，焦点位置をドリルで穴 をあけたフィルム上面に合わせて，フィルム上面からの反 射波を観察した．そのため，穴の部分ではフィルム上面か らの反射波が得られなくなるため黒く観察されるが，穴が ない部分ではフィルム上面からの反射波が得られるため白 く観察される.

同図に示されるように，周波数 $10 \mathrm{MHz}$ ，焦点径約 275 $\mu \mathrm{m}$ のプローブでは穴直径約 $110 \mu \mathrm{m}$ の穴を黒い円として 検出できた。しかし，その大きさは直径 $300 \mu \mathrm{m}$ を超える 大きさとして観察された。また，直径約 $80 \mu \mathrm{m}$ の穴の場 合には，穴の部分が周囲より黒く見えるため，穴の存在を 検出できるが，黒い円として穴を観察することができな かった。なお，直径約 $40 \mu \mathrm{m}$ の穴はほとんど観察できな かった．周波数 $25 \mathrm{MHz}$ ，焦点径約 $130 \mu \mathrm{m}$ のプローブの 場合には，輪郭が多少ぼやけるが直径約 $40 \mu \mathrm{m}$ 以上の穴 を黒い円として検出することができた。しかし，その大き さは実際の穴よりも大きく観察されている．表 2 にドリル 穴面積 $S_{1}$ と焦点面積 $S_{2}$ の比 $S_{1} / S_{2}$, ドリル穴直径 $D_{1}$ と焦 点径 $D_{2}$ の比 $D_{1} / D_{2}$ を示す. 図 4 と表 2 の結果から, 本研 究の範囲では焦点の面積の約 0.1 倍（焦点径の約 0.3 倍） 以上の直径の穴を検出できることがわかった。また，周波 数が高くなり焦点径が小さくなると穴はより明確に検出す ることができた。

なお，例えば周波数 $140 \mathrm{MHz}$, 焦点径 $6 \mu \mathrm{m}$ の超音波プ ローブで直径約 $40 \mu \mathrm{m}$ の穴を観察した結果では，穴の中 心が白く観察されている.これは, 測定時に除去できなかっ た気泡が穴の中に留まっており，超音波が気泡部分で反射

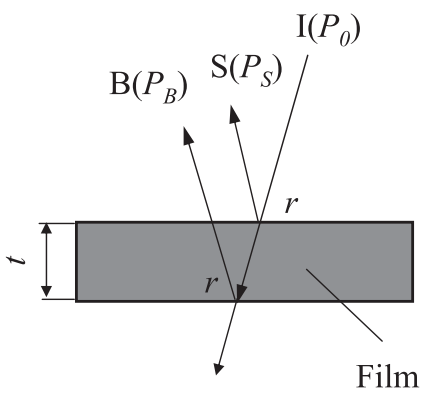

Fig. 6 Reflected echoes in film dipped in water

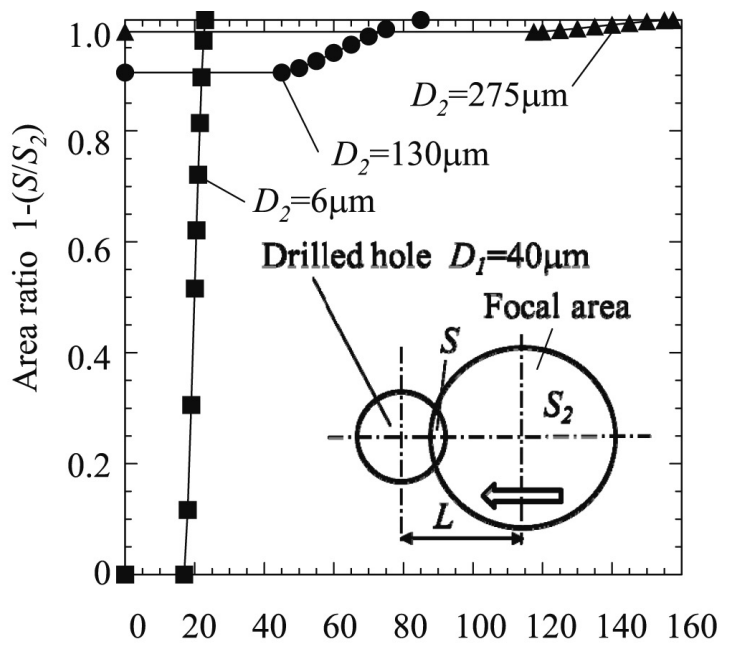

Distance between the center of the drilled hole and the center of the focus $L \quad(\mu \mathrm{m})$

Fig. 5 Area ratio 
し，大きな振幅の反射波が得られたため，周囲よりも白く 見えたと推察される.

超音波の焦点が円形であり，焦点内の超音波強度が一様 で，穴と焦点が重なった部分の面積の大きさがフィルム上 面で反射しない超音波の音圧の強さに比例すると仮定して， 超音波プローブを移動したときの重なった部分の面積変化 を幾何学的に求めた。結果を図 5 に示す。同図は, 横軸が 超音波の焦点と穴の中心間距離 $\mathrm{L}$, 縦軸は超音波プローブ の焦点の面積 $S_{2}$ と, $S_{2}$ から穴が重なり合った部分の面積 $S$ を引いた面積 $\left(S_{2}-S\right)$ の比 $\left(1-S / S_{2}\right)$ である.つま り，フィルム上面からの反射波振幅の大きさを表している と考えられる. 同図は, 穴直径 $40 \mu \mathrm{m}$ で, 超音波の焦点 径が $6 \mu \mathrm{m}, 130 \mu \mathrm{m}, 275 \mu \mathrm{m}$ の場合である. 同図に示さ れるように, 焦点径 $6 \mu \mathrm{m}$ の場合には超音波の焦点と穴の 中心間距離 $L$ が約 $23 \mu \mathrm{m}$ から面積比 $\left(1-S / S_{2}\right)$ が急激に

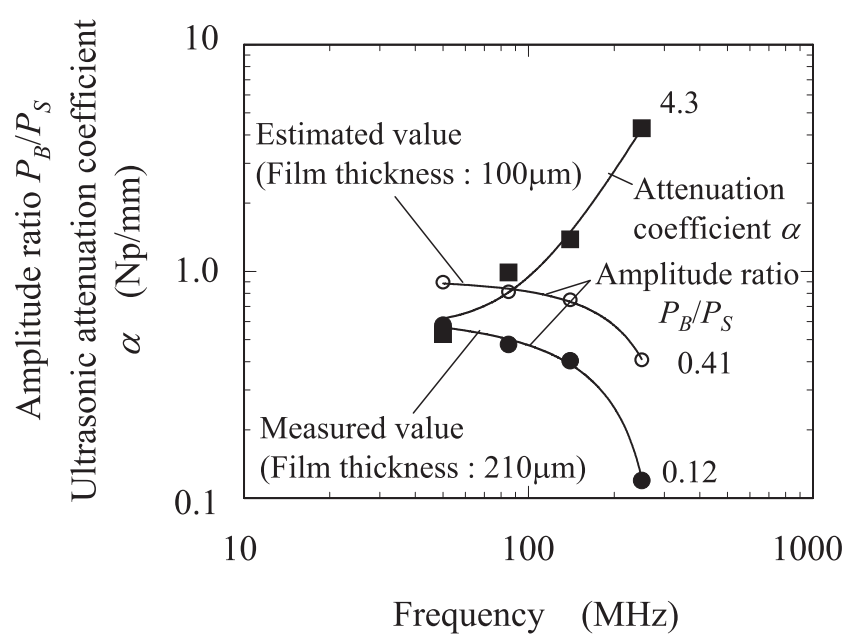

Fig. 7 Ultrasonic attenuation coefficient
小さくなり 0 になる．しかし，穴を検出できなかった焦点 径 $275 \mu \mathrm{m}$ の場合には距離 L が $157.5 \mu \mathrm{m}$ から面積比は小 さくなり始めるが，その変化量は小さく，0.98 までしか 減少しない。しかし, 輪郭が多少ぼやけるが穴を検出する ことができた焦点径 $130 \mu \mathrm{m}$ の場合には，距離 L が約 85 $\mu \mathrm{m}$ から面積比 $\left(1-S / S_{2}\right)$ が小さくなり約 0.9 まで小さ くなる. 図 4 や表 2 に示した結果と併せて考えると, 面積 比 $\left(1-S / S_{2}\right)$ が 0.9 以下であると検出できると考えられる.

以上のことから, 図 4 に示すように焦点径が小さければ 穴を明確に検出できるが，焦点径が大きいと穴が大きく観 察され，かつ，明確に観察されにくくなったことが分かる.

\section{2 超音波の減衰}

フィルム基板液晶セルで使用しているフィルムの減衰定 数を明らかにするために, 図 6 に示すように水浸法で試料 Bの減衰定数を測定した.

水中に置いた試料 $\mathrm{B}$ に超音波を投射すると，水とフィ ルム上面の境界面で一部が反射し, 反射波 S として観察 される.フィルム内部に透過した超音波は，フィルム内を 減衰しながら伝播してフィルム下面と水の境界面で反射し, 反射波 Bとして観察される。本研究で使用したフィルム の音速は約 $2260 \mathrm{~m} / \mathrm{s}$, 密度は約 $900 \mathrm{~kg} / \mathrm{m}^{3}$ であった。水 の音速を $1525 \mathrm{~m} / \mathrm{s}^{6)}$, 密度を $993 \mathrm{~kg} / \mathrm{m}^{37)}$ とすると, 水と フィルム, あるいはフィルムと水の境界面の反射率 $r$ の值 は，式(1)から約 0.15 となる.

フィルム上面からの反射波 S の音圧（振幅） $P_{S}$ とフィ ルム下面からの反射波 B の音圧（振幅） $P_{B}$ は，それぞれ 次式のようになる.

$$
P_{S}=P_{0} \cdot r
$$

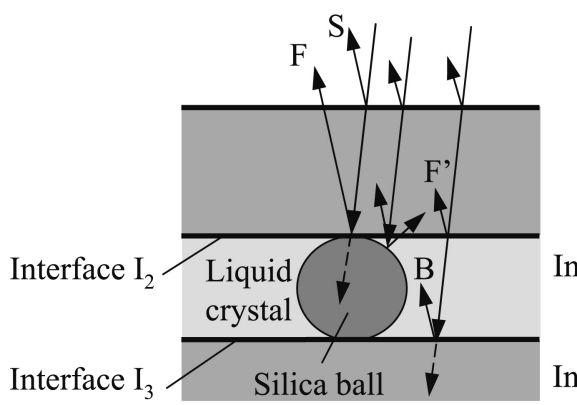

(a) Reflection of ultrasonic waves in test piece $\mathrm{C}-1$

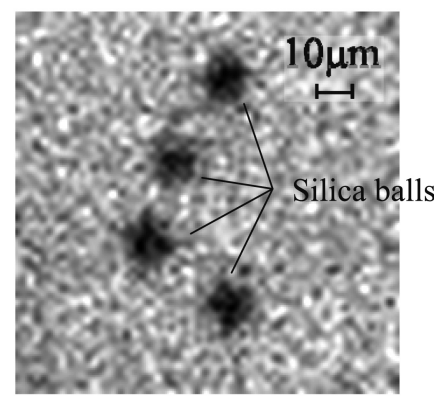

(c) Image of detected silica ball (Test piece $\mathrm{C}-1)$

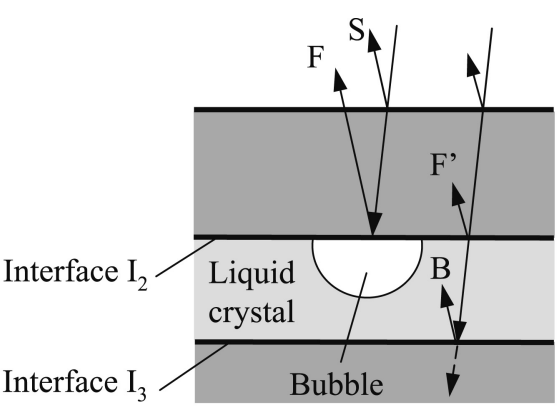

(b) Reflection of ultrasonic waves in test piece $\mathrm{C}-2$

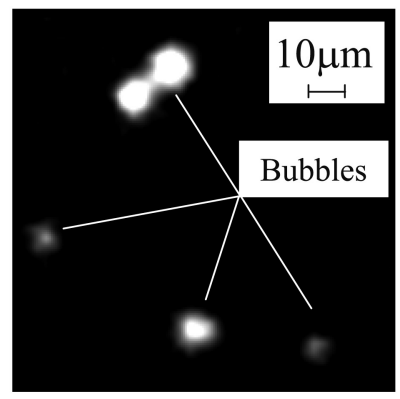

(d) Image of detected bubble (Test piece C-2)

Fig. 8 Detected results of silica balls and bubbles 


$$
P_{B}=P_{0} \cdot r(1-r)^{2} \exp (-2 t \alpha)
$$

ここで, $P_{0}$ : 送信波 I の音圧 (振幅), $\alpha$ : 減衰定数, で ある。

$$
\text { 式(2)と式(3)から，式(4)が得られる. }
$$

$$
P_{B} / P_{S}=(1-r)^{2} \exp (-2 t \alpha)
$$

フィルム上面と下面からの反射波振幅比 $P_{B} / P_{S}$, 水と フィルムの境界面の音圧反射率 $r$, フィルムの厚さ $t$ が明 らかであれば減衰定数 $\alpha$ を式(4)から求めることができる. そこで, 音圧反射率 $r$ を 0.15 , フィルム厚さ $t$ を $210 \mu \mathrm{m}$ として実験で得られた反射波振幅比 $P_{B} / P_{S}$ から減衰定数を 求めた.

超音波の周波数と減衰定数 $\alpha$, 反射波の振幅比 $P_{B} / P_{S}$, の関係を図 7 に示す．同図に示されるように，反射波振幅 比は指数関数的に小さくなり, 周波数 $250 \mathrm{MHz}$ では 0.12 となった。つまり，フィルム上面の反射波の $12 \%$ の振幅 が得られた. 減衰定数は周波数が高くなると指数関数的に 大きくなり, 周波数 $250 \mathrm{MHz}$ では約 $4.3 \mathrm{~Np} / \mathrm{mm}$ となる ことがわかった。

フィルム基板液晶セルで使用するフィルム基板の厚さが $100 \mu \mathrm{m}$ であるので, 求められた減衰定数の值から厚さ 100 $\mu \mathrm{m}$ の場合の反射波振幅比を求めた。 その結果, 周波数 $250 \mathrm{MHz}$ の場合でも反射波振幅比は 0.41 となった。つま り，フィルム基板を伝播して液晶との境界面で反射する反 射波振幅は，フィルム基板上面（水とフィルム基板の境界 面）の反射波振幅の約 $41 \%$ の大きさとなり, 反射波の検 出は十分に可能であると推察できる.

\section{3 シリカ球や気泡を混入した試料の観察}

フィルム基板液晶セル内部にスペーサとして直径 $5 \mu \mathrm{m}$ のシリカ球と異物として直径 $5.5 \mu \mathrm{m}$ のシリカ球が混入さ れている試料 C-1 を観察した結果を図 8 に示す. 使用し た超音波プローブは周波数 $250 \mathrm{MHz}$ ，焦点径 $6 \mu \mathrm{m}$ である. なお，同図(a)に示すフィルム基板と液晶の境界面 $\mathrm{I}_{2}$ に焦 点を合わせた結果，シリカ球を検出できなかった。この原 因としては, シリカ球がフィルム基板とほほ点接触してお り, その接触面積が非常に小さいため, シリカ球とフィル 厶基板との境界面からの反射波が非常に小さく，観察でき なかったと推察される.

そこで，境界面 $\mathrm{I}_{3}$ に焦点を合わせて観察した結果，同 図(c)に示されるように，スペーサあるいは異物として混 入されているシリカ球を黒い点として観察することができ た。これは, 液晶へ伝播した超音波がシリカ球の部分で散 乱などのために減衰して, 反射波振幅が小さくなったため と考元られる。この結果から, 液晶底面 (境界面 $\mathrm{I}_{3}$ )に焦 点を合わせて振幅変化を測定すれば，シリカ球のような微 小な異物やスペーサを観察できることがわかった.

次に, 同図 (b) に示す試料 $\mathrm{C}-2$ を使って気泡検出を行っ た。使用した超音波プローブは，周波数 $250 \mathrm{MHz}$ ，焦点 径 $6 \mu \mathrm{m}$ である. なお, 焦点はフィルムと水の境界面 $\mathrm{I}_{2} に$ 合わせて観察した.

同図 (d)に示すように, フィルムと気泡の境界面で超音 波がほぼ $100 \%$ 反射するため, シリカ球の場合とは異なり 気泡部分は白く観察された。なお，同図に示されるように，
今回の試料では約 $10 \mu \mathrm{m}$ 以下の気泡も観察することがで きた。

水平に置かれた試料では, 微小気泡は浮力によって上部 フィルムに密着し，面接触する．また，フィルムと気泡の 境界面で超音波はほほ全反射するため, シリカ球よりも気 泡の方が検出されやすいと考えられる.

今回の実験では直径 $5.5 \mu \mathrm{m}$ あるいは $5 \mu \mathrm{m}$ のシリカ球 を観察することができたので，同程度の大きさの気泡を観 察することが可能であると推察される.

\section{5. 結言}

超音波を利用したフィルム基板液晶セル中の微小気泡検 出方法について検討した結果，以下のような知見が得られ た。

1. 本研究の範囲内では, 超音波の焦点面積の約 0.1 倍(焦 点径の約 0.3 倍）の大きさの穴を観察できることがわ かった。この結果より, 直径 $10 \mu \mathrm{m}$ の気泡の場合に は, 焦点径が約 $33 \mu \mathrm{m}$ （表 1 から推定すると $85 \mathrm{MHz}$ 程度）の超音波プローブで検出できると推察される. また，焦点径 $6 \mu \mathrm{m}$ の超音波プローブを使った場合に は, 約 $1.8 \mu \mathrm{m}$ 程度の気泡まで検出できると推察され る.

2. 周波数 $250 \mathrm{MHz}$ の超音波がフィルムを伝播した場合, その減衰定数は $4.3 \mathrm{~Np} / \mathrm{mm}$ であった。この結果, 周 波数 $250 \mathrm{MHz}$ の超音波プローブを使用した場合でも， 厚さ $100 \mu \mathrm{m}$ のフィルム基板内を伝播した反射波振幅 は，フィルム基板表面からの反射波の約 $41 \%$ の大き さになると推察される.

3. 液晶を伝播して液晶とフィルム基板の境界面で反射し た超音波の振幅変化から，シリカ球のような微小な異 物やスペーサを検出できた。

4. 気泡を入れたモデル試料を観察した結果，フィルム基 板と水の境界面の反射波振幅変化から, 直径約 $10 \mu \mathrm{m}$ 以下の気泡を白く明確に観察することができた。

\section{謝辞}

測定用試料をご提供下さいました次世代モバイル用表示 材料技術研究組合に心から感謝いたします.

また，超音波映像装置をはじめとする測定機器をお貸し 下さいました株式会社日立エンジニアリング・アンド・ サービスに謝意を表します。

\section{参 考 文 献}

1 ) 斎藤文彦: 精密工学会誌, 63(4), 520 (1997)

2) 高橋一：精密工学会誌，67(2)，211(2001)

3 ) 池田泰, 水田安俊：テレビジョン学会技術報告, 18(29), 25 (1994)

$4 ）$ 田村賢一, 小野沢元久：日本機械学会講演論文集, 06 $-1,309(2006)$

5 ) 堀純也, 塩田賢志, 川村真未, 藤井佳子, 尾崎眞啓 : 医療機器学, 79(7), $152(2009)$

6 ）日本学術振興会製鋼第 19 委員会編：超音波探傷法(改 訂新版)，日刊工業新聞社，741(1979)

7 ) 伝熱工学資料(改訂第 4 版), 日本機械学会, 331 (1986) 